УДК 551.4.013: 911.52: 574.38

\title{
THE STUDY OF RELATIONSHIPS BETWEEN TERRAIN AND THE SPECTRAL CHARACTERISTICS OF ECOSYSTEMS IN UKRAINIAN CARPATHIANS USING REMOTE SENSING SATELLITE DATA
}

\author{
O. Mkrtchian \\ Ivan Franko National University of Lviv, \\ Doroshenko Str., 41, UA - 79000 Lviv, Ukraine \\ alemkrt@gmail.com
}

\begin{abstract}
Ukrainian Carpathians like many other mountainous areas possess significant ecological and societal values, thus requiring careful spatial management. This in its turn requires the careful consideration of relations between abiotic conditions and various ecosystem properties. While detailed spatial databases of these conditions and properties are still lacking for many regions, currently available remote sensing satellite data are the indispensable source of the spatially distributed detailed ecological information. Digital elevation models and multispectral images are especially useful for the acquisition of detailed, up-to-date and cheap spatial data on ecological factors and conditions.

In this study the modern statistical methods of principal component analysis and the canonical correlation analysis have been applied to reveal the structure in the relationships between land surface reflectance values in different wavelength ranges and to investigate the relationships between the revealed image principal components and the set of topographic characteristic and indexes for the study area in Ukrainian Carpathians.

Principal component analysis of LANDSAT 7 ETM+ image bands allowed to isolate three independent spatial components that together reveal the structure in the relationships between the land surface reflectance values in different spectral channels. Canonical correlation analysis allowed to discern two main canonical roots, proving the existence of rather strong relationships between the land surface morphometry and its spectral characteristics. The most important terrain factor that influences the land and vegetation cover structure appeared to be the elevation, while the other significant factors included a set of topographic characteristics and indices.
\end{abstract}

Key words: remotely sensed imagery, digital elevation models, topographic variables, principal component analysis, canonical analysis, Ukrainian Carpathians.

Mountainous areas usually play a significant ecological and conservational role and function as focal points of regional biodiversity, hotspots of rare species habitats, places where large spans of natural and semi-natural ecosystems are preserved. This, together with the economical values of mountains as reservoirs of valuable resources, their cultural values as places where local historical cultural customs and practices remain intact, their values as desirable significant destinations for tourism and recreation, determine the need of careful spatial management and planning of land use and resource utilization activities that affect mountain ecosystems.

This said, mountains are often characterized by dynamic processes and changes that can be activated under the human impacts. Abiotic conditions of climate, relief, geological substrate and soils in mountains often show sharp spatial gradients that reflect on the distribution of species, ecosystems and their properties. Therefore, spatial

(C) Mkrtchian O., 2017 
planning in mountainous areas requires the careful consideration of relations between abiotic conditions and various ecosystem properties.

Carpathians are one of the largest mountain ranges in Europe, providing an essential habitat and refuge for many endangered species of plants and animals, containing Europe's largest areas of virgin forests, and constituting a major ecological, economic, cultural, recreational and living environment in the heart of Europe, shared by numerous peoples and countries. Ukrainian Carpathians (the narrow part of the elongated Carpathian arch inside the borders of Ukraine) are the largest and highest mountain range of the country, hosting the large part of Ukraine biodiversity, being an important refuge and corridor for plants and animals as well as providing indispensable ecosystem services and being an important area for local and regional tourism and recreation. Ukrainian Carpathians have been experiencing dramatic changes in land use practices during last several decades caused by sharp and profound socioeconomic transformations, leading to corresponding transformations of land cover, changes in the distribution and structure of many ecosystems, in the courses of a set of geomorphologic and hydrologic processes, including dangerous and detrimental ones. Terrain plays an important function as both the factor determining the course of a set of important geosystem and ecosystem processes, and the indicator of the various properties of these systems hidden from direct observation.

The importance of terrain features as a major factor defining the landscape structure and ecosystem distribution, is especially notable in mountainous areas with their sharp ecological gradients. At the same time, the detailed spatial characterization of terrain features is presently possible thanks to the emergence of fine-resolution DEMs. Their analysis makes possible to define process-oriented terrain attributes topographic variables that correspond to ecological gradients that are either conditioned or indicated by terrain features. The set of these gradients presumably makes up the biotope, while the corresponding ecologically meaningful topographic variables quantify biotope composition and could be used in the detailed analysis of the distribution of biotopes and their constituent ecological gradients.

Our research is aimed at the delineation of ecologically meaningful topographic variables, which can subsequently be subjected to multivariate analysis to reveal the spatial structure of abiotic factors variability connected with terrain. Two kinds of such analysis can be suggested: the principal component analysis that explores the general orthogonal axes of ecological variation in landscape (landscape ordination analysis), and the cluster analysis that partitions the area into relatively ecologically homogeneous units.

Abiotic ecological factors include the characteristics of geologic substratum, relief, climate, soils, and hydrologic processes. Their spatial gradients are the major factor determining the richness of habitats and the $\beta$-diversity in a landscape [21]. The gradients of ecological factors are often divided into direct gradients that have immediate physiological importance (e.g., temperature, illumination, water availability, soil $\mathrm{pH}$ ) and indirect gradients which have no direct physiological relevance but which imply some direct gradients or their combinations and which are more easily measured in the field (e.g., elevation, geology, slope) [1,2].

Data on spatial distribution of the mentioned abiotic factor are therefore crucial for understanding the spatial distribution of ecosystems and their properties for the effective management and land use planning in mountainous areas. These data, 
however, are often contained in the different sources of different kinds, often in nondigital form, lacking metadata, thus requiring their careful coordination before mutual utilization. New data acquiring usually requires laborious and time-consuming field studies, especially in the cases of large study areas. These problems are especially relevant for the developing nations, with their out-of-dated data sources and lacks of funding for fresh studies.

However, new promising solution came into sight recently in the form of detailed spatially distributed remote sensing datasets obtained from satellite missions. These data sources have a set of advantages, among which are the availability and accessibility of timely datasets and their low costs, as many datasets of rather high quality have recently become available free of charge via specialized cites on the web. Yet, while satellite data can be the indispensable source of the detailed spatially distributed ecological information, they provide only indirect clues and indicators, requiring the correct and effective interpretation of their data to derive ecologically meaningful and valuable information.

Two major types of satellite remote sensing data are of particular interest for the ecological studies: digital elevation models (DEMs) and multispectral images. DEMs are used for the characterization and analysis of land surface morphometry as the product of both geomorphological processes and geologic structure. DEM data analysis allows to calculate topographic variables that make efficient predictors of habitat characteristics [12]. The multispectral images allow analyzing the spectral characteristics of landscape that imply the vegetation cover structure, the composition and state of forest stands, as well as the structure of land use. DEMs and the multispectral satellite radiometric images are the most commonly used ancillary environmental data for the spatial prediction and mapping of soil and vegetation [7]. Ready to use datasets representing both types of data are presently available free of charge, with spatial resolution and quality sufficient enough for regional ecological studies.

Topographic variables derived from DEM analysis relate closely to the factors and manifestations of processes that determine habitat characteristics (like solar energy and water redistribution, soil erosion and accumulation). One example is the Topographic wetness index (TWI) introduced by Beven and Kirkby [5], defined as $T W I=\ln \left(A_{s} / \tan \beta\right)$, where $A_{s}$ is a local catchment area and $\beta$ - local slope. It reflects on the balance of water accumulation and drainage over a local neighborhood and has been shown to correlate well with a set of soil characteristics [4, 10]. As these, together with the water availability and regimen strongly affect habitat characteristics, this index could have a significant value as an ecological indicator. For instance, it has been used for predicting wetlands locations in small catchments across a wide range of geological, topographic and climatic conditions [15]. Thus, such topographic indexes can be regarded as indirect ecological gradients sensu Austin [1].

Another kind of the spatially distributed ecologically meaningful indexes can be derived from the transformations and combinations of different spectral channels of multispectral imagery. Such indexes will characterize the reflective qualities of the landscape in respect to the sunlight with different wavelengths. The best known and most widely used of these is the Normalized difference vegetation index (NDVI), 
easily determined and mapped using the digital analysis of spatial imagery. It is calculated by the formula

$$
N D V I=\frac{N I R-R E D}{N I R+R E D}
$$

where $R E D$ and $N I R$ are the spectral reflectance measurements acquired in the red and near-infrared spectral channels, respectively [19]. Values of NDVI often correlate with the Leaf Area Index, plant productivity, biomass, chlorophyll concentration in leaves, fractional vegetation cover, and some other ecosystem properties which together indicate the degree of presence and the current state of natural vegetation of the area [11]. Another example is a Normalized difference water index (NDWI) which is sensitive to changes in liquid water content of vegetation canopies [9]; having a similar structure with $N D V I$, it differs from the latter by the spectral channels used in it calculation.

While there are plenty of studies concerning digital relief morphometry analysis, and the studies on the ecological interpretation of multispectral image data, there is the definite lack of researches that aim at the combined analysis and integration of these two types of data. Such an analysis will clarify a notion of the spatial distribution of basic ecosystem properties as being determined by or related to the spatial distribution of the basic abiotic conditions, making thus possible to insight into the spatial relations between the properties of land cover and vegetation and their abiotic environment.

Our empirical study aims at the analysis of the relationships between the land surface reflectance in different spectral channels and the set of land surface morphometry characteristics as determined for our study area. While the former is indicative of the vegetation cover structure, the state and composition of forest stands, as well as the land use structure, the latter being the product of geomorphologic processes and geologic structure is indicative of some important abiotic ecological factors.

The case study of the research is a $90 * 70 \mathrm{~km}$ rectangular region in the central part of the Ukrainian Carpathians. The diagonal of this rectangle roughly matches with the axis of the Carpathians arc, thus the study area encompasses parts of its northern and southern macroslopes and the surrounding foothill planes.

Two freely available geospatial datasets have been used for the study: SRTM v. 4.1 DEM and LANDSAT 7 ETM+ multispectral image set. The processed SRTM data version 4.1 [13] are available on-line from CGIAR Consortium for Spatial Information (http://srtm.csi.cgiar.org). These data are in decimal degrees, in geographic coordinate system with datum WGS84, with $90 \mathrm{~m}$ pixel resolution. LANDSAT 7 ETM+ multiband image (NASA, 2009) has been obtained from the on-line USGS archive (http://glovis.usgs.gov). The LANDSAT 7 ETM+ image consists of 8 band layers acquired on October 13, 2009 with $30 \mathrm{~m}$ resolution each, already being projected to UTM coordinate system (datum WGS84) [17]. LANDSAT images were acquired on May 02, 2000 and have been terrain-corrected by supplier (for the detailed metadata, look at aforementioned website).

Our preprocessing of data consisted in bringing them to the common resolution and coordinate system. For this aim, SRTM DEM has been projected onto UTM coordinate system while the LANDSAT 7 ETM+ dataset has been resampled to $90 \mathrm{~m}$ spatial resolution to match the resolution of the DEM. 
The analysis of the data has been carried in two steps. In the first step, the principal component analysis was applied to the set of LANDSAT 7 ETM+ image bands to isolate the three independent spatial components that together reveal the structure in the relationships between the land surface reflectance values in different spectral channels. The second step of analysis consisted in applying the canonical correlation analysis to analyze the relationships between these components and the set of topographic characteristic and indexes. Canonical correlation analysis is a statistical technique that investigates the relationship between two sets of variables. It is based on the extraction of canonical variates (roots) that are defined as the correlated weighted sums of variables from each set. Each of the canonical roots can be conceived as describing some underlying "latent" variable that represents the distinct kind of relationship between the two sets [20]. The relationships were analyzed in this way between the first set of three LANDSAT 7 ETM+ image principal components and the second set that included such spatial variables as elevation values, slopes, the Topographic wetness index, the index of relief erosion potential [16], and the index of solar energy redistribution by local topography [14]. The three roots have been derived that describe the independent components of the common spatial variation in the two sets of variables.

The results of the principal components analysis of the LANDSAT 7 ETM+ image data are given in tables 1-3. The first principal component shows rather strong negative correlations with most of the spectral bands, thus corresponding to the overall "brightness" of the surface (Fig. 1). It also strongly correlates with elevation values, thus the increase in the surface elevation in the area is often accompanied by the decrease in its reflectivity. Visual analysis of its spatial structure and comparing it with the topographic maps reveal its strong positive relations with the presence and density of forest stands. It is also positively correlated with the slope values.

Table 1

Principle component analysis of LANDSAT 7 ETM+ image data: eigenvalues of correlation matrix

\begin{tabular}{|c|c|c|}
\hline Component & Eigenvalue & \% Total - variance \\
\hline 1 & 3.009 & 75.22 \\
\hline 2 & 0.727 & 18.18 \\
\hline 3 & 0.249 & 6.21 \\
\hline
\end{tabular}

Table 2

Principle component analysis of LANDSAT 7 ETM+ image data: factor loadings of the spectral bands

\begin{tabular}{|c|c|c|c|c|}
\hline $\begin{array}{c}\text { Landsat } \\
\text { band number }\end{array}$ & $\begin{array}{c}\text { Wavelengths } \\
\text { (micrometers) }\end{array}$ & Component 1 & Component 2 & Component 3 \\
\hline $\mathbf{2}$ & $0.52-0.60$ & -0.95 & 0.18 & 0.23 \\
\hline $\mathbf{3}$ & $0.63-0.69$ & -0.89 & 0.45 & 0.06 \\
\hline $\mathbf{4}$ & $0.76-0.90$ & -0.70 & -0.70 & 0.15 \\
\hline $\mathbf{5}$ & $1.55-1.75$ & -0.91 & -0.09 & -0.41 \\
\hline
\end{tabular}


Table 3

Principle component analysis of LANDSAT 7 ETM+ image data: correlation coefficients of principal components with topographical variables

\begin{tabular}{|l|c|c|c|}
\hline Topographical variables & Component 1 & Component 2 & Component 3 \\
\hline ELEVATION & 0.436 & 0.436 & 0.015 \\
\hline SLOPE & 0.362 & 0.133 & 0.038 \\
\hline CTI & -0.16 & -0.079 & -0.014 \\
\hline EROSIVITY FACTOR & 0.18 & 0.032 & 0.023 \\
\hline SOLAR FACTOR & -0.061 & 0.073 & -0.052 \\
\hline
\end{tabular}

The second component also positively correlates with the elevation values, but its relations with other topographic characteristic and indices appeared to be very different from those of the first component. The second component appears to discriminate well between deciduous and coniferous forests: dense beech forest stands produce especially low values. This component also shows very strong $(r=0.95)$ negative correlation with the well-known NDVI index. Low values of this component (and high values of NDVI) generally indicate the presence of deciduous (mostly beech) forests characterized by high values of biological productivity and biodiversity. The second component also better differentiates between different anthropogenic land uses and land cover types.

The first and the second principal components also correspond well to the two first components of the tasseled cap transformation [6]. The third component shows very weak linear correlation with the topographic characteristic and indices, however its visual analysis revealed that its high values strongly associate with the locations of subalpic meadows. This component can thus effectively be used for the detection and monitoring of the location and extent of valuable subalpic grassland communities in Ukrainian Carpathians with a number of rare and endangered species.

The images of these components are given in Fig. 2 and Fig. 3.

Canonical correlation analysis has been used to analyze the relationships between these components and the set of DEM-derived topographic characteristic and indices. Most of the variability in the two sets of variables has been explained by the first canonical root, which is strongly correlated with the elevation values (Tab. 4-6). The second root positively correlates with the slope values and the mass movement potential and negatively with the solar radiation influx. 


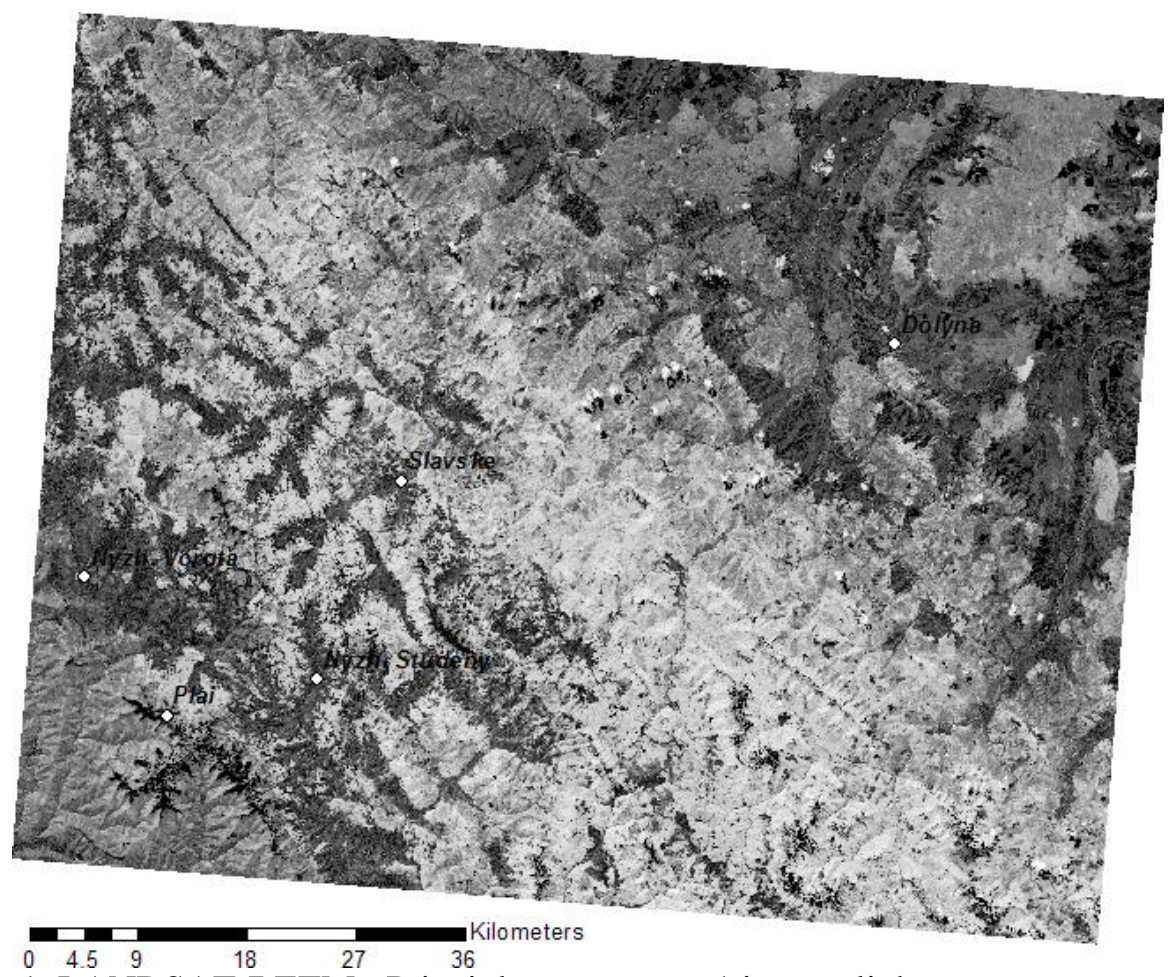

Fig. 1. LANDSAT 7 ETM+ Principle component 1 image; lighter tone corresponds to higher values.

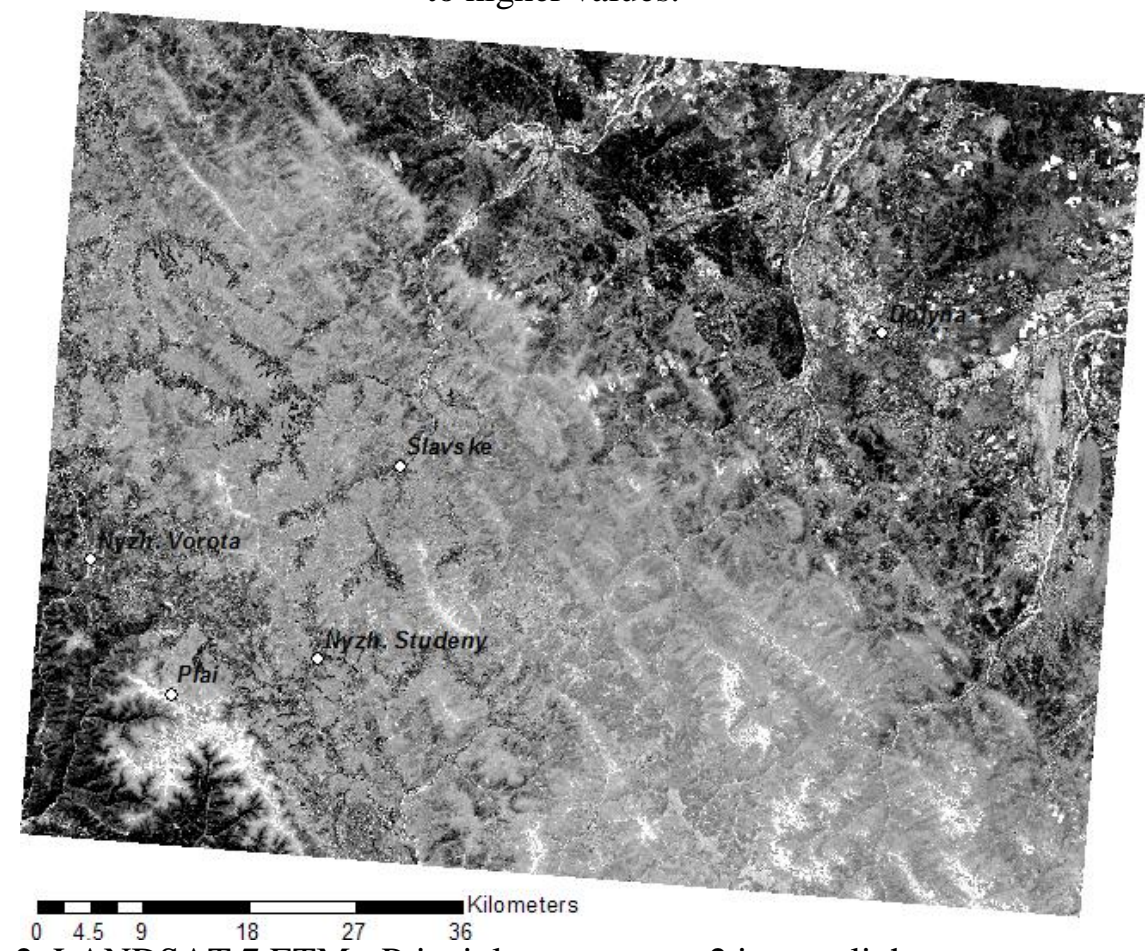

Fig. 2. LANDSAT 7 ETM+ Principle component 2 image; lighter tone corresponds to higher values. 
Canonical roots' eigenvalues

Table 4

\begin{tabular}{|l|c|c|c|c|}
\hline & Root 1 & Root 2 & Root 3 & Root 4 \\
\hline Eigenvalue & 0.416 & 0.065 & 0.009 & 0.001 \\
\hline
\end{tabular}

Table 5

Canonical correlations

\begin{tabular}{|c|c|c|c|}
\hline Canonical root & Canonical - R & $\begin{array}{c}\text { Canonical - } \\
\text { R-sqr. }\end{array}$ & Chi-sqr. \\
\hline 1 & 0.645 & 0.416 & 477756.2 \\
\hline 2 & 0.256 & 0.065 & 59963.7 \\
\hline 3 & 0.094 & 0.009 & 7457.2 \\
\hline 4 & 0.027 & 0.001 & 556.1 \\
\hline
\end{tabular}

Table 6 Canonical factor loadings

\begin{tabular}{|l|c|c|c|c|}
\hline Topographical variables & Root 1 & Root 2 & Root 3 & Root 4 \\
\hline ELEVATION & -0.98 & -0.023 & 0.194 & -0.016 \\
\hline SLOPE & -0.523 & -0.729 & 0.405 & 0.03 \\
\hline PLAN CURVATURE & -0.143 & -0.135 & -0.336 & 0.386 \\
\hline $\begin{array}{l}\text { PROFILE } \\
\text { CURVATURE }\end{array}$ & 0.19 & -0.012 & 0.224 & 0.583 \\
\hline CTI & 0.256 & 0.268 & -0.127 & -0.084 \\
\hline $\begin{array}{l}\text { EROSIVITY } \\
\text { FACTOR }\end{array}$ & -0.226 & -0.419 & 0.418 & -0.271 \\
\hline SOLAR FACTOR & -0.06 & 0.649 & 0.632 & 0.034 \\
\hline
\end{tabular}

The results of this study prove the existence of rather strong relationships between the land surface morphometry and its spectral characteristics. These relationships imply the more fundamental relations between the ecosystem distribution and properties and the character of abiotic conditions.

The two major moprhometric factors of land cover differentiation appeared to correspond to the distinction between the high and low altitudes (canonical root 1), and also between the steep shady slopes and sunlit flat areas (canonical root 2). The analysis of the spatial distribution of the canonical factors scores and residuals can 
indicate the state of vegetation, the degree of its correspondence to abiotic factors and conditions, the character and degree of anthropogenic disturbances.

Multispectral images can be used to derive characteristics and indices relevant to the assessment of the state of vegetation cover and its properties that determine the ecological value and significance of habitats. The widely used NDVI index has been shown to correlate with plant [3] and animal [18] species diversity, as well as the carbon fluxes and storages $[8,11]$. In our case the analysis has shown that areas with high NDVI values (that mostly correspond to highly productive deciduous forests) are generally found on steep slopes in low elevations (Fig. 3). It is at variance with the prevailing conservation strategy in Ukrainian Carpathians, where most protected areas are located in high altitudes.

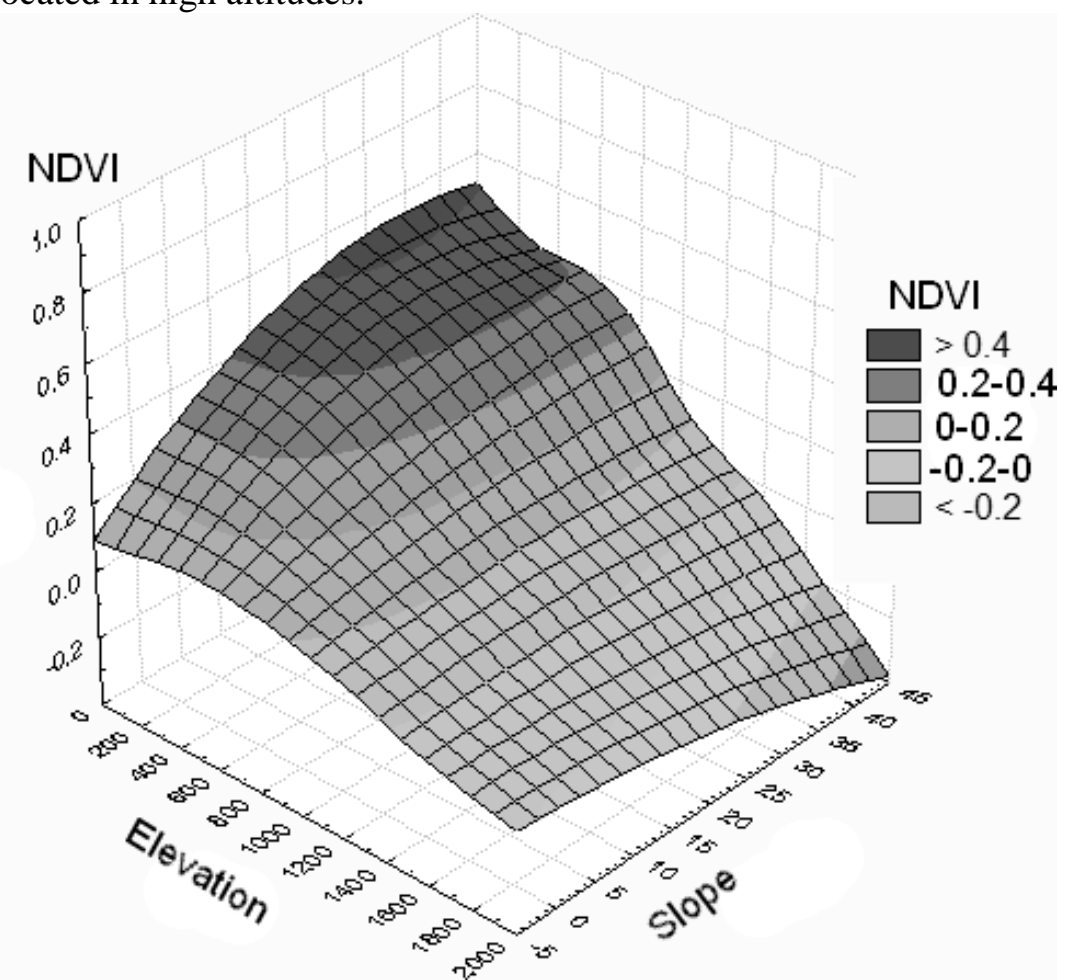

Fig. 3. The distribution of the average NDVI values in relation to elevation and slope

The current availability of detailed remotely sensed satellite data makes it a useful tool for analyzing the relationships between the ecosystem distribution and properties and the abiotic factor that shape them. The results obtained in this study reveal the presence and character of such relationships in the study area in the central part of Ukrainian Carpathians. While this study mostly analyzes local dependencies, the inclusion of non-local measures (e.g., the averages and variances of variables calculated inside the moving windows of variable sizes) and also texture measures can possibly provide more insights into the spatial relationships, ecological structures and processes in mountainous landscapes. 


\section{REFERENCES}

1. Austin M.P. Continuum concept, ordination methods and niche theory // Annu. Rev. Ecol. Syst. - 1985. - 16. - P. $39-61$.

2. Austin M.P., Smith T.M. A new model for the continuum concept // Vegetatio. 1989. - 83. - P. $35-47$.

3. Bawa K., Rose J., Ganeshaiah K. N., Barve N., Kiran M. C., Umashaanker R. Assessing biodiversity from space: an example from the Western Ghats, India // Conservation Ecology. - 2002. - 6(2). URL: http://www.consecol. org/vol6/iss2/art7.

4. Behrens T., Zhu A.-X., Schmidt K., Scholten T. Multi-scale digital terrain analysis and feature selection for digital soil mapping // Geoderma. - 2010. - 155 . - P. $175-185$.

5. Beven K., Kirkby M. J. A physically based, variable contributing area model of basin hydrology // Bulletin of Hydrologic Sciences. - 1979. - 24 (1). - P. 43-69.

6. Crist E. P., Cicone R. C. A Physically-Based Transformation of Thematic Mapper Data - The TM Tasseled Cap // IEEE Transactions on Geoscience and Remote Sensing. - 1984. - 22 (3). - P. 256-263.

7. Dobos E., Micheli E., Baumgardner M. F., Biehl L., Helt T. Use of combined digital elevation model and satellite radiometric data for regional soil mapping // Geoderma. - 2000. - 97 (3-4). - P. 367-391.

8. Frank A., Karn J. Vegetation indices, $\mathrm{CO}_{2}$ flux, and biomass for Northern Plains grass-lands // Journal of Range Management. - 2003. - 56. -P. 382-387.

9. Gao Bo-cai. NDWI - A normalized difference water index for remote sensing of vegetation liquid water from space // Remote Sensing of Environment. - 1996. 58 (3). - P. 257-266.

10. Gessler P. E., Moore I. D., McKenzie N. J., Ryan P. J. Soil-landscape modeling and spatial prediction of soil attributes // International Journal of GIS. - 1995. - 9 (4). - P. 421-432.

11. Glenn E. P., Huete A. R., Nagler P. L., Nelson S. G. Relationship between remotely-sensed vegetation indices, canopy attributes and plant physiological processes: what vegetation indices can and cannot tell us about the landscape // Sensors. - 2008. - 8(4). - P. 2136-2160.

12. Guisan A., Zimmermann N. E. Predictive habitat distribution models in ecology // Ecological Modelling. - 2000. - 135. - P. 147-186.

13. Jarvis A., Reuter H. I., Nelson A., Guevara E. Hole-filled seamless SRTM data V4 // International Centre for Tropical Agriculture (CIAT). - 2008. URL: http://srtm.csi.cgiar.org.

14. Kumar L., Skidmore A. K., Knowles E. Modelling topographic variation in solar radiation in a GIS environment // Int. J. for Geogr. Information Science. - 1997. 11(5). - P. 475-497.

15. Merot Ph., Squividant H., Aurousseau P. Testing a climato-topographic index for predicting wetlands distribution along a European climate gradient // Ecological Modelling. - 2003. - 163. - P. 51-71.

16. Mitasova H. J., Hofierka M., Zlocha R., Iverson L. Modeling topographic potential for erosion and deposition using GIS // Int. J. of Geogr. Information Science. $-1996 .-10(5)$. - P. $629-641$. 
17. NASA Landsat Program. Landsat 7 ETM+ scene L71185026_02620070522, Geocover. - USGS, Sioux Falls, 2009. Obtained 10/13/2009.

18. Oindo B.O., de By R.A., Skidmore A. K. Interannual variability of NDVI and bird species diversity in Kenya // International Journal of Applied Earth Observation and Geoinformation. - 2000. - 2(3-4). - P. 172-180.

19. Rouse J. W., Haas R. H., Schell J. A., Deering, D. W. Monitoring vegetation systems in the Great Plains with ERTS // Third ERTS Symposium, NASA SP351(I). - 1973. - P. 309-317.

20. StatSoft, Inc. Electronic Statistics Textbook. Tulsa, OK: StatSoft, 2012. URL: http://www.statsoft.com/textbook/

21. Whittaker R. H. Vegetation of the Siskiyou Mountains, Oregon and California // Ecological Monographs. - 1960. - 30. - P. 279-338.

\title{
ДОСЛІДЖЕННЯ ЗВ'ЯЗКІВ МІЖ РЕЛЬЕФОМ ТА СПЕКТРАЛЬНИМИ ХАРАКТЕРИСТИКАМИ ЕКОСИСТЕМ УКРАЇНСЬКИХ КАРПАТ 3 ВИКОРИСТАННЯМ ДАНИХ СУПУТНИКОВОГО ЗНІМАННЯ
}

\author{
О. Мкртчян \\ Львівський національний університет імені Івана Франка, \\ вул. П.Дорошенка 41, Львів, 79000. Україна, e-mail: alemkrt@gmail.com
}

Українські Карпати, як і багато інших гірських територій, становлять значну цінність 3 природоохоронної та суспільної точок зору, що вимагає належної уваги до просторового управління цими територіями. Це, в свою чергу, потребує ретельного вивчення зв'язків між абіотичними умовами та різними властивостями екосистем. Хоча для багатьох регіонів світу наразі відсутні достатньо детальні бази даних щодо таких умов і властивостей, наявні в наш час дані супутникового знімання $\epsilon$ незамінним джерелом детальної просторово розподіленої екологічної інформації. Особливо цінними в цьому відношенні цифрові моделі рельєфу та мультиканальні геозображення, які дозволяють отримувати детальну, актуальну в часі та дешеву просторову інформацію щодо екологічних умов і чинників.

В даному дослідженні використано сучасні статистичні методи аналізу головних компонент та канонічного кореляційного аналізу для виявлення структури зв'язків між значеннями відбивної здатності земної поверхні у різних довжинах хвиль, та дослідження зв'язків між виявленими головними компонентами геозображення та набором морфометричних характеристик та індексів, в межах дослідної ділянки в Українських Карпатах.

Аналіз головних компонент спектральних каналів геозображення LANDSAT 7 ETM+ дозволив виділити три незалежні просторові компоненти, які разом виявляють структуру зв'язків між значеннями відбивної здатності земної поверхні у різних спектральних каналах. Канонічний кореляційний аналіз дозволив виокремити два головні канонічні корені, довівши існування досить сильного зв'язку між морфометрією земної поверхні та iii спектральними характеристиками. Найбільш важливим фактором рельєфу, який впливає на структуру наземного і вегетаційного покрову, виявилась абсолютна висота, в той час як інші значущі фактори включали низку морфометричних характеристик та індексів.

Ключові слова: дистанційні зображення, цифрові моделі рельєфу, морфометричні характеристики, аналіз головних компонент, канонічний аналіз, Українські Карпати. 